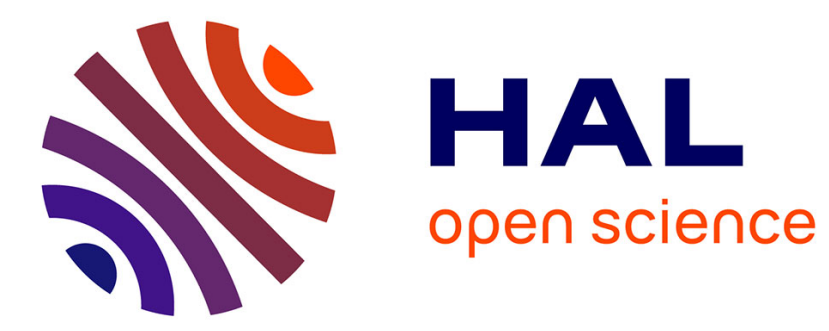

\title{
LPV control for power source coordination - application to electric vehicles energy management systems
}

Waleed Nwesaty, Antoneta Iuliana Bratcu, Olivier Sename

\section{To cite this version:}

Waleed Nwesaty, Antoneta Iuliana Bratcu, Olivier Sename. LPV control for power source coordination - application to electric vehicles energy management systems. ECC 2014 - 13th European Control Conference, Jun 2014, Strasbourg, France. pp.2649-2654. hal-00968382

\section{HAL Id: hal-00968382 https://hal.science/hal-00968382}

Submitted on 2 Aug 2016

HAL is a multi-disciplinary open access archive for the deposit and dissemination of scientific research documents, whether they are published or not. The documents may come from teaching and research institutions in France or abroad, or from public or private research centers.
L'archive ouverte pluridisciplinaire HAL, est destinée au dépôt et à la diffusion de documents scientifiques de niveau recherche, publiés ou non, émanant des établissements d'enseignement et de recherche français ou étrangers, des laboratoires publics ou privés. 


\title{
LPV control for power source coordination - application to electric vehicles energy management systems
}

\author{
W. Nwesaty, A.I. Bratcu and O. Sename
}

\begin{abstract}
This paper presents an $\mathbf{L P V} / H_{\infty}$ control strategy applied to power source coordination on board of averagepower electric vehicles. The proposed approach concerns frequency separation of responses between three power sources in order to satisfy power demand of vehicle's electrical motor, taking into account that sources are expected to work within distinct frequency ranges. The three sources - fuel cell, battery and ultracapacitor - are connected in parallel to a common DC-bus which supplies the electrical motor.

The idea is to use the weighting functions associated to the $\mathbf{L P V} / H_{\infty}$ controller to determine auxiliary power source behaviors - battery and ultracapacitor - and to minimize the variation of fuel cell current and the DC-bus voltage. As a result, DC-bus voltage is regulated at $150 \mathrm{~V}$, while the fuel cell provides mean power to the electrical motor.

MATLAB $^{\circledR} /$ Simulink $^{\circledR}$ numerical simulation is used to validate the proposed approach by using two driving scenarios, namely Normalized European Driving Cycle (NEDC) and the driving cycle proposed by IFSTTAR (Institut Français des Sciences et Technologies des Transports, de l'Aménagement et des Réseaux).

Keywords: LPV control, optimal control, electrical power systems, power source coordination, electric vehicle, fuel cell, battery, ultracapacitor.
\end{abstract}

\section{INTRODUCTION}

$$
\begin{aligned}
W_{e} & =\left[\begin{array}{cc}
W_{e_{-} \Delta V d c} & 0 \\
0 & W_{e_{-} \Delta I f c}
\end{array}\right] \\
W_{u} & =\left[\begin{array}{cc}
W_{u_{-} \Delta I b a t} & 0 \\
0 & W_{u_{-} \Delta I u c}
\end{array}\right]
\end{aligned}
$$

T he last decade has raised the importance and interest of electric vehicle to stop the growing in need for petrol and in pollutant emissions [1]. Car manufacturers are developing clean power sources as fuel cells or photovoltaic panels, and proposing on-board energy management systems in order to minimize energy consumption [2]. Alternately, auxiliary power sources can be added in order to increase the efficiency by collecting the reversed power during braking. These secondary sources, like batteries and ultracapacitors, reduce power loss and consequently increase efficiency and autonomy [3]. On the other hand, it is also important during the power coordination - to respect the working conditions of each source [4]. For instance, the battery state

Manuscript received October 21, 2013.

Waleed NWESATY, Antoneta Iuliana BRATCU, Olivier SENAME are with Grenoble Institute of Technology, GIPSA-lab, Control Systems Department, 11 Rue des Mathématiques, Grenoble Campus BP46, F-38402, Saint-Martin d'Heres, France (e-mails: waleed.nwesaty@gipsa-lab.grenobleinp.fr; antoneta.bratcu@gipsa-lab.grenoble-inp.fr; olivier.sename@gipsalab.grenoble-inp.fr). of health depends on the dynamic of the current, i.e., on the discharging/charging cycle.

There are two terms to describe a power source with respect to its power supply ability [5]:

- Source with high power density, which is able to provide high power for a short period of time with high dynamic characteristics; ultracapacitors are typical examples of such type of sources, and

- Source with high energy density, which is able to provide power during long periods of time with slow dynamic characteristics; fuel cells and batteries belong to this class of sources.

The above features are emphasized by Ragone's classification [6]. One can see that ultracapacitors have high power density since they can provide several kilowatts in less than a second, so ultracapacitors can support to abruptly varying loads. On the other hand, fuel cells can provide power for several hours when the load is in steady state or when charging other auxiliary sources like battery and ultracapacitor. Thus, fuel cells are well suited to provide energy when power demand varies very slowly. The battery appears to be well suited to play a role between ultracapacitor and fuel cell, which happens when the power demand is changing moderately slow (here, term "slow" is relative to battery type and depends on charging and discharging characteristics). In addition, the battery is used to energize different equipment within the vehicle. Battery could also play the role of main source when the fuel cell is disconnected or empty.

This paper studies the case of a power supply system consisting of three power sources, each of which is controlled by means of a DC-DC converter. Sources are connected in parallel to the load (consisting of an electrical motor with its associated converter) through a DC-bus (Fig. 1). The fuel cell is considered as the main source of power and connected to a 1-quadrant boost converter, which only allows unidirectional power flow, whereas a battery and an ultracapacitor represent auxiliary sources able to cover variations of power demand that are placed in relatively high frequency. In this way, lifetime of main source is extended by restricting its utilization at low frequency. Each auxiliary source is connected to a 2-quadrant boost converter, which allows charging/discharging. The full electrical scheme of the system is shown in Fig. 1. The element values are provided in the Appendix.

The control objective is to regulate the DC-bus voltage at $150 \mathrm{~V}$ with a tracking error of $\pm 10 \mathrm{~V}$ in the presence of load power perturbation. This is achieved thanks to power flow coordination between the sources with respect to their 
frequency characteristics, which in consequence leads to improve utilization and extend life of both fuel cell and battery.

In the literature, most of the studied systems consist of two power sources such that a fuel cell and an auxiliary source like a battery or an ultracapacitor [7]. In general, each source is treated as a current source whose current should be controlled according to a given reference. This current reference is generated using different methods such as PIDcontroller-based strategies [8], fuzzy logic control [9], or strategies based on high/low-pass filtering the global current reference in order to achieve frequency separation between the power sources [10],[11]. LQG control has also been used to generate the current references [12].

This paper proposes for the first time a Linear Parameter Varying (LPV) approach to coordinate efficiently auxiliary power sources (battery and ultracapacitor). Given that the global system exhibits bilinear dynamics, current references are generated by means of an $\mathrm{LPV} / H_{\infty}$ controller. The proposed method guarantees the global stability of the closedloop system and specifies the frequency domain of each source by means of the associated weighting functions. The current references generated by this algorithm cover the high-frequency variations of load current, while the fuel cell is supposed to supply the steady-state load current (mean value). A PI controller is used to generate the required fuel cell's current reference by regulating the DC-bus voltage within a cascade control structure. For the application content, it is important to notice that each auxiliary source's current reference is generated by two stages: one stage is used to regulate the state of charge (SOC) with a slow dynamic, thus providing the low-frequency component of current reference to the low-level current control loop (fastdynamic), the other stage provides high-frequency component of current reference corresponding to the load current variation (this stage contains the LPV controller which is the contribution of this paper (see Fig. 2).

This paper is structured as follows. Section 2 discusses the nonlinear model of the system. Section 3 presents the proposed control structure and details the $\mathrm{LPV} / H_{\infty}$ controller design. The simulation results are outlined and discussed in Section 4. Lastly, in Section 5, conclusion and future work are presented.

\section{MODELING}

The studied system consists of three boost converters associated to power sources; these converters are connected in parallel to a single DC-bus whose voltage is supposed to be regulated at $150 \mathrm{~V}$ by using a PI controller. The electrical model of the studied system is represented in Fig. 1. Converters are represented by their respective averaged models. Energy conservation laws lead to a nonlinear model which embeds the DC-bus voltage PI controller dynamic:

$$
\begin{array}{cc}
\dot{I}_{f c}= & \frac{1}{L_{f c}}\left[V_{f c}-V_{d c}\left(1-\alpha_{f c}\right)\right] \\
\dot{I}_{u c}= & \frac{1}{L_{u c}}\left[V_{u c}-V_{d c} \alpha_{u c}\right] \\
\dot{I}_{b a t}= & \frac{1}{L_{b a t}}\left[V_{b a t}-V_{d c} \alpha_{b a t}\right] \\
\dot{V}_{d c}= & \frac{1}{C_{D C}}\left[\frac{-1}{R_{D C}} V_{d c}-I_{L o a d}+I_{f c}\left(1-\alpha_{f c}\right)\right. \\
& \left.+I_{b a t} \alpha_{b a t}+I_{u c} \alpha_{u c}\right] \\
I_{f c}^{*}= & K_{p} e+K_{i} \int e d t
\end{array}
$$

where $I_{f c}, I_{b a t}$, and $I_{u c}$ are currents of fuel cell, battery, and ultracapacitor, respectively. $V_{f c}, V_{b a t}$, and $V_{u c}$ are the respective source voltages. $\alpha_{f c}, \alpha_{b a t}$, and $\alpha_{u c}$ are the respective converter duty ratios. $C_{D C}$ and $R_{D C}$ are the DCbus capacitor and resistance, respectively. $V_{d c}$ is the DC-bus voltage, $I_{\text {Load }}$ is the load current. $e=V_{d c}{ }^{*}-V_{d c}$ is the DC-bus voltage tracking error. $I_{f c}{ }^{*}$ is the fuel cell current reference. $K_{p}$ and $K_{i}$ are DC-bus voltage PI controller proportional and integral gain respectively.

DC-bus voltage closed loop has a second-order dynamics; we are interested in its linearized model in variations around different operating points defined by the DC-bus voltage setpoint $(150 \mathrm{~V})$ and the mean value of load current.

$$
\left.\begin{array}{rl}
\Delta \dot{V}_{d c}= & \frac{1}{C_{D C}}\left[\frac{-1}{R_{D C}} \Delta V_{d c}+\left(1-\alpha_{f c}\right) \cdot \Delta I_{f c}\right. \\
& \left.+\alpha_{b a t} \cdot \Delta I_{b a t}+\alpha_{u c} \cdot \Delta I_{u c}-\Delta I_{\text {Load }}\right] \\
\Delta \dot{I}_{f c}^{*}=- & K_{i} \cdot \Delta V_{d c}-K_{p} \cdot \Delta \dot{V}_{d c}
\end{array}\right\}
$$

Notation " $\Delta$ " denotes variation. Load current variation $\Delta I_{\text {Load }}$ acts as a disturbance for system (6). The basic idea of the proposed control strategy is to consider current

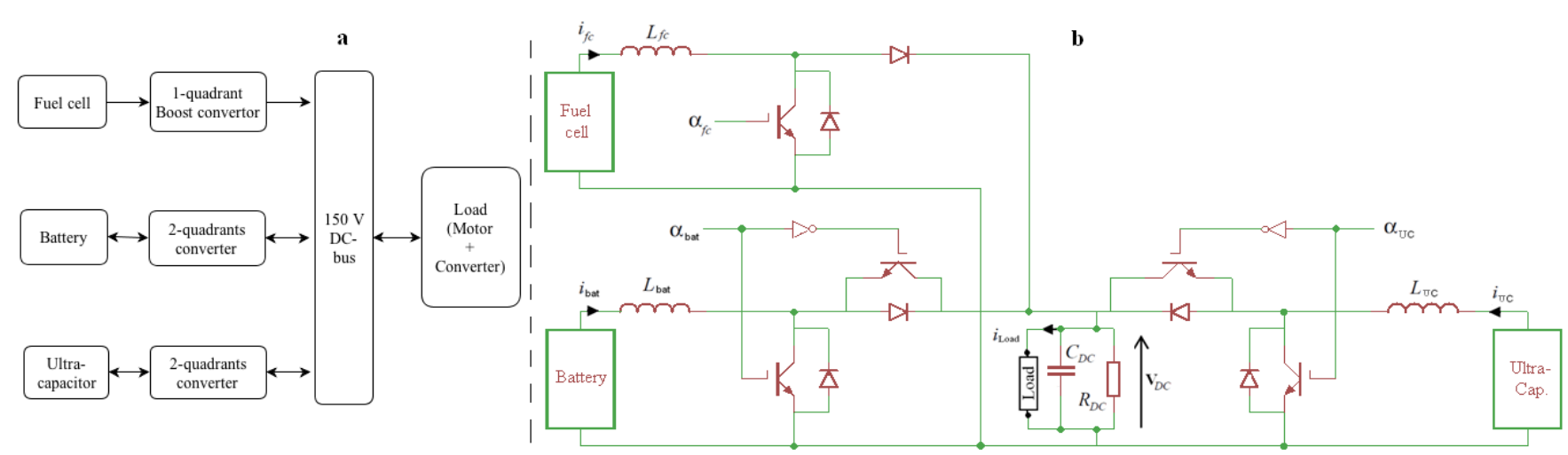

Fig. 1: a: System block representation. b: corresponding electrical system. 
variations of the two auxiliary sources $\left(\Delta I_{b a t}\right.$ and $\left.\Delta I_{u c}\right)$ as control inputs for system (6), which must ensure disturbance rejection (Fig. 2). In this paper, $\Delta I_{b a t}$ and $\Delta I_{u c}$ correspond to the LPV polytopic control design, where controllers in vertices of the polytope comply with the requirement of separating sources in frequency, and these controllers are obtained by an $H_{\infty}$ control synthesis.

We will consider next that $I_{f c}{ }^{*}=I_{f c}$ since this current reference is served by low-level current control loop with faster dynamic compared with the loop generating $I_{f c}{ }^{*}$ (PI controller in the DC-bus voltage control loop - see (Fig. 2)).

\section{CONTROL DESIGN}

In this section the control approach used for the onboard power source coordination is detailed. The control objective is to regulate the DC-bus voltage at $150 \mathrm{~V}$ within an accepted error of $\pm 10 \mathrm{~V}$, and to guarantee working in different frequency ranges for the three sources (fuel cell, battery and ultracapacitor) in order to prolong their life. The control diagram is shown in Fig. 2, where all current control loops have been grouped together to emphasize that they are characterized by fast closed-loop time response. Similarly, the state of charge (SOC) control loops are characterized by slow closed-loop dynamics; here the needed local controller is very briefly presented and design of these loops is not detailed in this work [13]. The LPV method that allows to coordinate the use of both battery and ultracapacitor sources to assist the main source delivering the power is detailed next.

Measured values of voltages and currents are used as feedback variables for control purpose and supposed to be available in real time.

\section{A. PI current control loops (fuel cell, battery and ultraca- pacitor)}

The current of each source must be controlled to prevent from exceeding admissible limits. To this aim, PI-controllerbased control loops are built around plant transfer functions given by (1), (2) and (3) respectively. References of these control loops are provided by the outer loops, i.e., by the
DC-bus voltage loop for fuel cell current, and by the LPV loop and the SOC loops for the auxiliary source currents (see control block diagram in Fig. 2). PI controllers are tuned to satisfy fast dynamics compared to the higher-level control loops.

\section{B. PI DC-bus voltage control loop}

The aim of this control loop is to regulate DC-bus voltage at reference value $V_{d c}{ }^{*}=150 \mathrm{~V}$; fuel cell as main source is in charge with this task. A PI controller is used to this end, while the auxiliary sources (battery and ultracapacitor) are required to contribute for reducing variations of DC-bus voltage, as well as of fuel cell current.

\section{PI state of charge (SOC) control loops (battery and ultracapacitor)}

States of charge of auxiliary sources are maintained within imposed limits by generating $I_{b a t}{ }^{0}$ and $I_{u c}{ }^{0}$ which are the averaged components of the corresponding current references. Two PI controllers charge the battery and the ultracapacitor to be ready to use, these loops are tuned to ensure a dynamic slower than any other loop dynamic. Battery SOC reference is chosen $100 \%$ - representing full charge - while ultracapacitor SOC reference is chosen $50 \%$ to preserve source capability to absorb/provide high currents in response to load current variation.

\section{D. $L P V / H_{\infty}$ design}

System (6) is considered in LPV/ $H_{\infty}$ design. The objective is to minimize the variation of DC-bus voltage and also the variation of the fuel cell current by controlling the battery and ultracapacitor currents in desired frequency ranges thanks to $H_{\infty}$ optimization with its associated weighting functions. The generalized plant has three inputs, namely, the load (electrical motor) current, which is considered as disturbance input, and variations of auxiliary sources' currents, which are the control inputs. Plant's outputs are the DC-bus voltage variation, which should be minimized to be within $\pm 10 \mathrm{~V}$, and the variation of the fuel cell current.

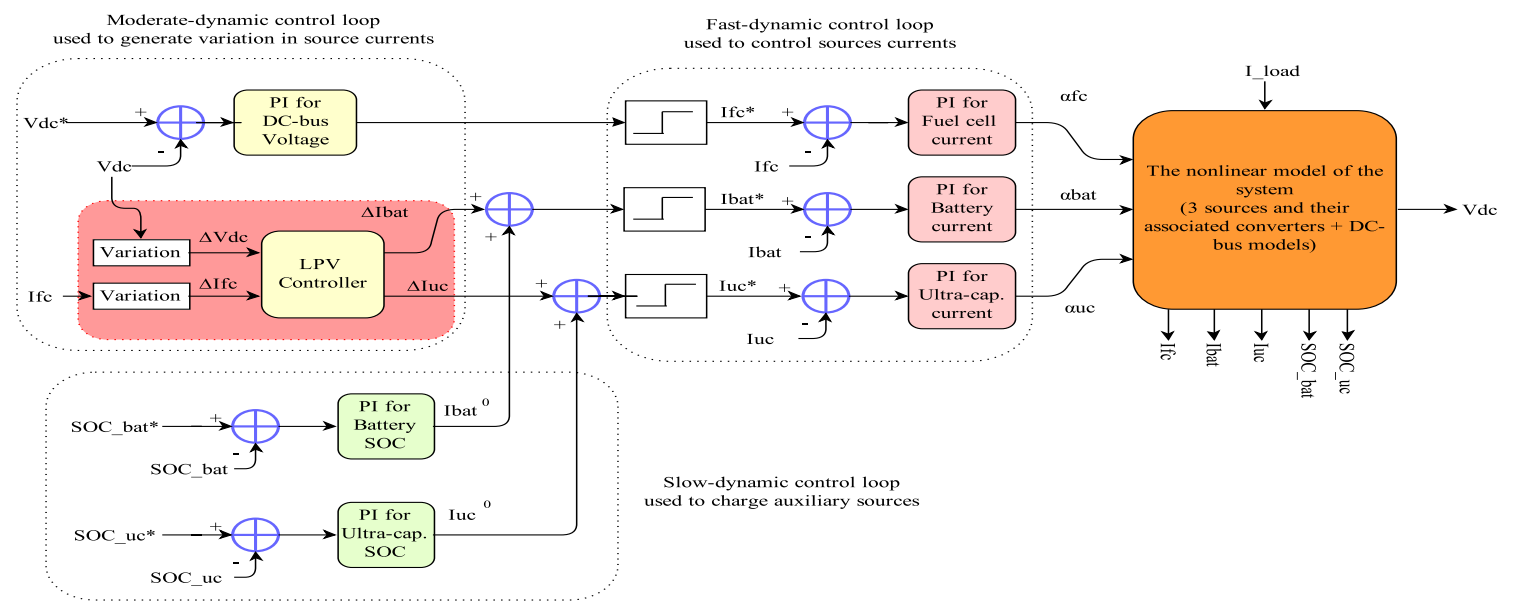

Fig. 2: Global control block diagram. 
Selection of weighting functions is the key to confine contribution of each source to a desired frequency range; as shown in Fig. 3, DC-bus voltage and fuel cell current variations are bounded by first-order weighting functions $W_{e \Delta V_{d c}}, W_{e \Delta I_{f c}}$, respectively, while battery and ultraca-

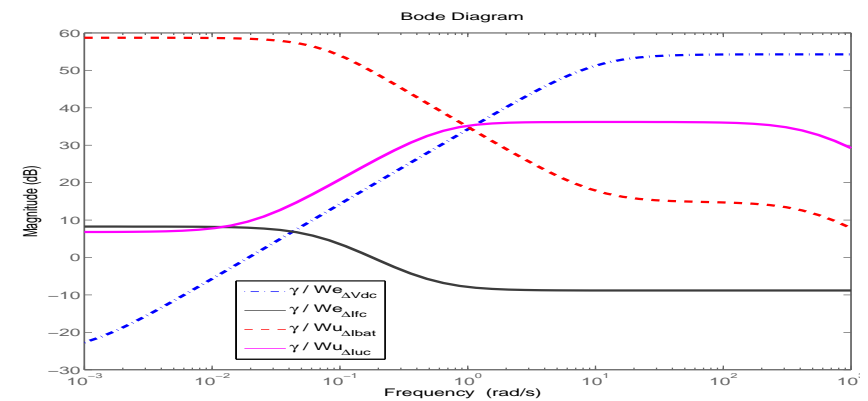

Fig. 3: Weighting functions used to confine frequency ranges of battery and ultracapacitor current variations.

pacitor current variations are bounded by fourth-order lowpass and band-pass weighting functions $W_{u \Delta I_{b a t}}, W_{u \Delta I_{u c}}$, respectively. This choice for the weighting functions leads to good frequency separation between all power source responses. Therefore, fuel cell supplies current in lowfrequency range, while the auxiliary sources provide currents in relatively high-frequency range to fulfill the power demands. Folding frequencies are chosen as $\omega_{n \Delta I_{f c}}=0.05$ $\mathrm{rad} / \mathrm{s}, \omega_{n \Delta I_{b a t}}=0.1 \mathrm{rad} / \mathrm{s}$ and $\omega_{n \Delta I_{u c}}=1 \mathrm{rad} / \mathrm{s}$. These choices of folding frequencies depend on the desired performances corresponding to the source types (e.g., maximum admissible current gradient specified by the manufacturer).

System (6) could be represented according to the following LPV form:

$$
\left\{\begin{array}{llll}
\dot{x} & = & A(\rho) \cdot x+B_{1} \cdot \omega+B_{2}(\rho) \cdot u \\
y & = & {\left[\begin{array}{ll}
1 & 0 \\
0 & 1
\end{array}\right] x}
\end{array}\right.
$$

where state vector $x=\left[\begin{array}{ll}\Delta V_{d c} & \Delta I_{f c}\end{array}\right]^{T}$ is composed of DC-bus voltage and fuel cell current variations, respectively, $\omega=\Delta I_{\text {Load }}$ is load current variation which represents the disturbance input, $u=\left[\begin{array}{ll}\Delta I_{b a t} & \Delta I_{u c}\end{array}\right]^{T}$ is the control input vector composed of variations of battery and ultracapacitor current, respectively. Matrices in (7) are:

$$
\begin{gathered}
A=\left[\begin{array}{cc}
\frac{-1}{C_{D C} R_{D C}} & \frac{\left(1-\rho_{1}\right)}{C_{D C}} \\
\left(-K_{\text {int }}+\frac{K_{p}}{C_{D C} R_{D C}}\right) & -\frac{\left(1-\rho_{1}\right) K_{p}}{C_{D C}}
\end{array}\right] \\
B_{1}=\left[\begin{array}{c}
\frac{-1}{C_{D C}} \\
\frac{K_{p}}{C_{D C}}
\end{array}\right] \quad B_{2}=\left[\begin{array}{cc}
\frac{\rho_{2}}{C_{D C}} & \frac{\rho_{3}}{C_{D C}} \\
-\frac{K_{p} \rho_{2}}{C_{D C}} & -\frac{K_{p} \rho_{3}}{C_{D C}}
\end{array}\right]
\end{gathered}
$$

Note that $\mathrm{A}$ and $\mathrm{B} 2$ depend on parameter vector $\rho=$ $\left[\begin{array}{lll}\rho_{1} & \rho_{2} & \rho_{3}\end{array}\right]^{T}=\left[\begin{array}{lll}\alpha_{f c} & \alpha_{b a t} & \alpha_{u c}\end{array}\right]^{T}$. System (7) can be represented in following generalized form:

$$
\left[\begin{array}{l}
\dot{x} \\
z \\
y
\end{array}\right]=\left[\begin{array}{ccc}
A(\rho) & B_{1} & B_{2}(\rho) \\
C_{1} & D_{11} & D_{12} \\
C_{2} & D_{21} & D_{22}
\end{array}\right]\left[\begin{array}{l}
x \\
\omega \\
u
\end{array}\right]
$$

Parameter vector $\rho$ is bounded by $[0.1,0.9]$ (this corresponds to the duty ratio accepted variation from $10 \%$ to $90 \%$ ). Each parameter is supposed to be independent from the other parameters, and the system can be represented by a polytopic form with $2^{3}=8$ vertices as follows [14]:

$$
\left[\begin{array}{cc}
A(\rho) & B(\rho) \\
C & D
\end{array}\right]=\sum_{1}^{8} \alpha_{i}(\rho)\left[\begin{array}{cc}
A_{i} & B_{i} \\
C_{i} & D_{i}
\end{array}\right], \quad \sum_{1}^{8} \alpha_{i}=1
$$

The plant used in controller synthesis is represented in Fig. 4. In conclusion, an LPV controller noted $K(\rho)$ can be found according to formula:

$$
K(\rho)=\sum_{1}^{8} \alpha_{i}(\rho) K_{i}
$$

with:

$$
\begin{gathered}
\alpha_{i}(\rho)=\frac{\left.\prod_{j=1}^{3} \mid \rho_{j}-C\left(w_{i}\right)_{j}\right) \mid}{\left.\prod_{j=1}^{3} \mid \overline{\rho_{j}}-\underline{\rho_{j}}\right) \mid}>0, \quad \sum_{1}^{8} \alpha_{i}=1 \\
\overline{\rho_{j}}=\max \left(\rho_{j}\right)=0.9 \quad \underline{\rho_{j}}=\min \left(\rho_{j}\right)=0.1
\end{gathered}
$$

where $\omega_{i}$ are the edges of the polytope formed by the extreme values of the parameter vector $\rho . C\left(w_{i}\right)_{j}$ is the $j^{t h}$ component of the vector $C\left(w_{i}\right)$ defined as:

$C\left(w_{i}\right)_{j}=\left\{\rho_{j} \mid \rho_{j}=\overline{\rho_{j}}\right.$ if $\omega_{i}=\underline{\rho_{j}}$, otherwise $\left.\rho_{j}=\underline{\rho_{j}}\right\}$.

All controllers $K_{i}$ are synthesized as $H_{\infty}$ controllers with state space representations $K_{i}=\left[\begin{array}{cc}A_{i} & B_{i} \\ C_{i} & D_{i}\end{array}\right]$. The optimization problem is represented by a set of linear matrix inequalities and solved using Yalmip/Sedumi solver [14],[15]. Fig. 5 presents the closed-loop Bode diagrams for the transfer functions of interest in all 8 system operating points; one can note that they respect the weighting functions in Fig. 3.

\section{SIMULATION RESULTS}

Numerical simulation is performed to prove the effectiveness of the proposed LPV/ $H_{\infty}$ control approach. Nonlinear electrical models (represented by equations 1, 2, 3 and 4) are used for simulation purpose. Two different load profiles are considered, Normalized European Driving Cycle (NEDC) and the driving cycle proposed by IFSTTAR institute [10], [11] (Fig. 6 and Fig. 10, respectively), in order to serve as

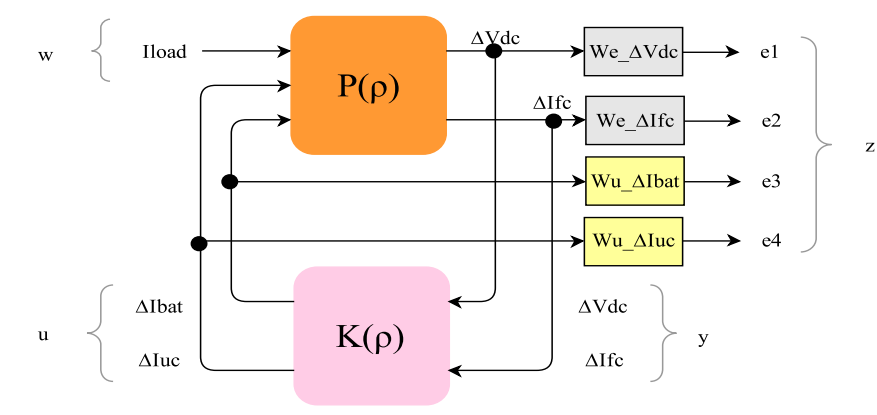

Fig. 4: $H_{\infty}$ Robust control design block diagram. 
simulation scenarios. These profiles represent various driving conditions including acceleration, deceleration, steady speed and full brake and allow assessing performance of DC-bus voltage regulation and the way how the three sources are coordinated to provide the demanded power.

\section{A. Normalized European Driving Cycle (NEDC)}

This load profile corresponds to a harsh environment driving cycle (e.g., within the city), where acceleration followed by full brake occurs frequently. Fig. 6 shows the load current, which is an image of the vehicle speed.

One can see that the system is able to provide the demanded power, while the DC-bus voltage shown in Fig. 7 is well regulated at voltage reference $150 \mathrm{~V}$ within the allowed error \pm 10 V. Fig. 8 shows how currents of different sources are provided to the system, with fuel cell supplying the average current and ultracapacitor handling the peak variations, while battery provides the midrange-frequency current. In order to complete the analysis, the power spectral density of each source current is computed, then it is normalized with respect to the maximum power delivered by each source. Fig. 9 shows the power delivered by each source with respect to frequency. According to Fig. 9, the three sources are separated in frequency and correspond to the chosen weighting functions, where fuel cell supplies the lowfrequency current, ultracapacitor handles the high-frequency current variation, and battery contribution is in between the two other sources.

\section{B. IFSTTAR Driving Cycle}

Fig.10 shows different scenario of load current, which challenges the vehicle's power supply system; it may, for example, correspond to road between cities. Demanded power is provided by the three sources in their respective frequency ranges, while DC-bus voltage is well regulated within the accepted tracking error.

Like in the previous case, power demand is well shared between the three sources according to demanded frequency ranges. Fig. 11 and Fig. 12 show how high-frequency power variations are entirely supported by ultracapacitor.
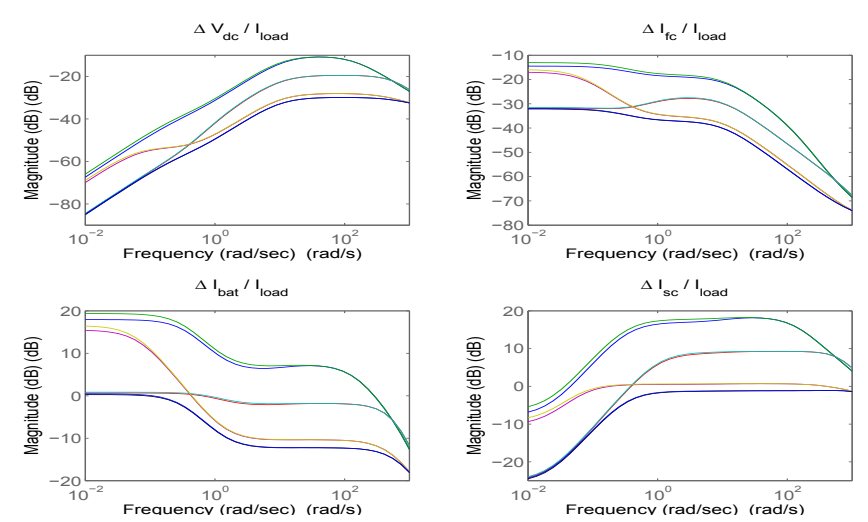

Fig. 5: Closed-loop Bode diagrams of $\frac{\Delta V_{d c}}{I_{\text {load }}}, \frac{\Delta I_{f c}}{I_{\text {load }}}, \frac{\Delta I_{\text {bat }}}{I_{\text {load }}}$ and $\frac{\Delta I_{u c}}{I_{\text {load }}}$ in all 8 system operating points.

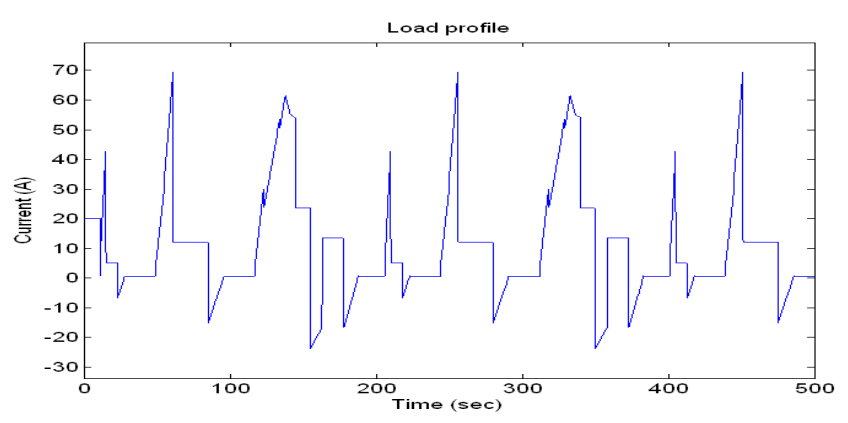

Fig. 6: NEDC load current profile used in simulation.

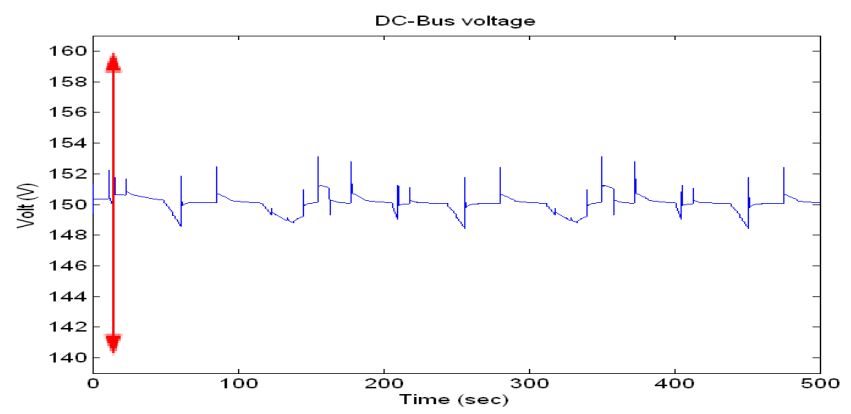

Fig. 7: DC-bus regulated voltage corresponding to NEDC load profile, voltage is well regulated at $150 \mathrm{~V} \pm 10 \mathrm{~V}$ as an admissible error.

\section{CONCLUSION}

In this work, an $\mathrm{LPV} / H_{\infty}$ control approach is applied to design an energy management strategy based on coordination of three different kinds of power sources - fuel cell, battery and ultracapacitor - on board of an electric vehicle. Sources are connected in parallel with their associated DC-DC boost converters on a common DC-bus and attached to the load (an electrical motor with its converter). The control objective is to regulate the DC-bus voltage by means of controlling sources' currents provided to the DC-bus. Fuel cell and battery must be protected from sudden power variations in order to prolong their life, therefore each source should be operated in the frequency range that suits better its features as either high-energy-density or high-power-density source, according to Ragone's taxonomy. In other words, fuel cell is managed to provide the mean power, while ultracapacitor provides/absorbs the sudden variations of power demand. The battery's role in placed in between the two other sources, besides it is used to energize the different vehicle's equipment.

The nonlinear electrical system is simulated using two different load profiles, Normalized European Driving Cycle (NEDC) and driving cycle of IFSTTAR. These profiles contain acceleration, deceleration, steady speed and full brake sequences. The proposed method proves good performance in regulating the DC-bus voltage and supplying the load according to a frequency-separation strategy of power sharing between sources.

For future work, fuel cell could only be required to recharge the other sources at its maximum efficiency working point, thus increasing the power efficiency of the system. 


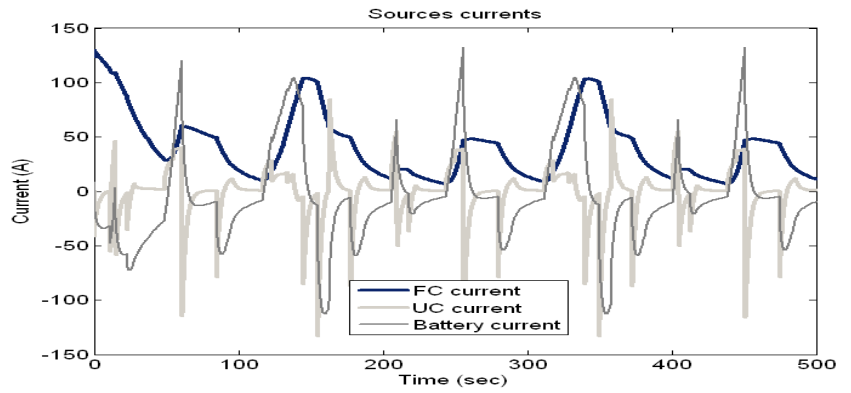

Fig. 8: Sources currents corresponding to NEDC load profile.

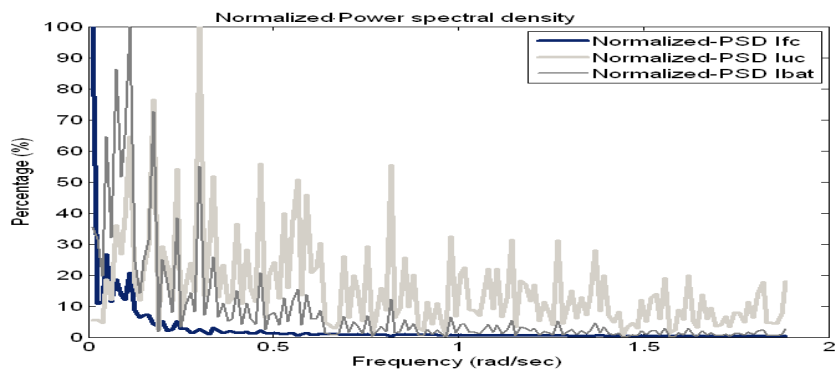

Fig. 9: Normalized power spectral density of the sources' currents corresponding to NEDC load profile.

For this reason switching control could be applied to switch between two control laws, taking into consideration two different system models, namely including/excluding the fuel cell.

Note also that the proposed power sharing strategy can easily be generalized to any kind of on-board energy management system, potentially containing any number of power sources. Experimental validation should also be envisaged.

\section{APPENDIX}

Ultracapacitor converter: $L_{u c}=0.5 \mathrm{mH}$; Battery converter: $L_{b a t}=0.5 \mathrm{mH}$; Fuel cell converter: $L_{f c}=6 \mu \mathrm{H}$; DC-bus: $V_{D C}=150 \mathrm{~V}, C_{D C}=22 \mathrm{mF}, R_{D C}=100 \mathrm{k} \Omega$. PI DC-bus voltage control loop: $K_{p}=0.071, K_{i}=4.41$. PI fuel cell current control loop: $K_{p}=0.5, K_{i}=0.1$. PI battery current control loop: $K_{p}=0.01, K_{i}=0.8$. PI ultracapacitor current control loop: $K_{p}=0.01, K_{i}=0.4$. PI battery/ultracapacitor SOC control loop: $K_{p}=0.001, K_{i}=0.015$.

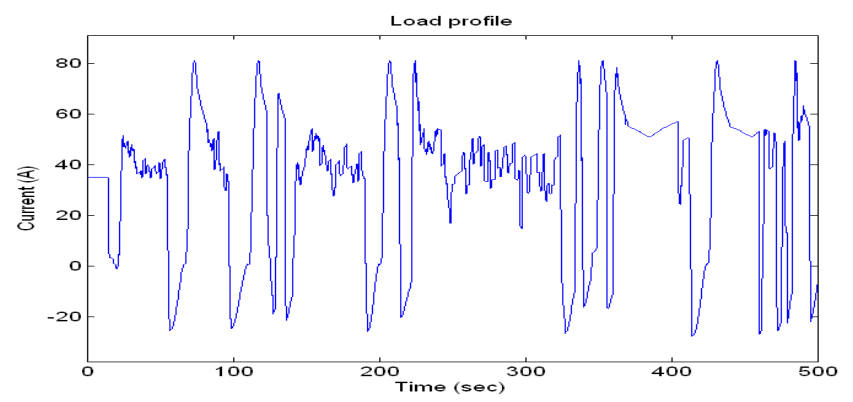

Fig. 10: IFSTAR load current profile used in simulation.

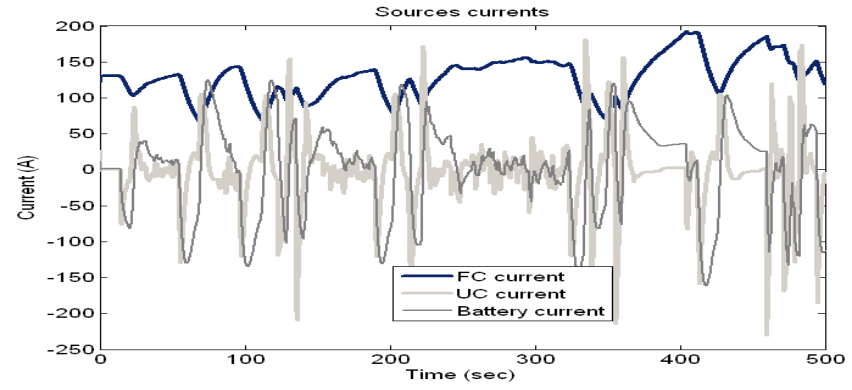

Fig. 11: Source currents corresponding to IFSTTAR load current profile.

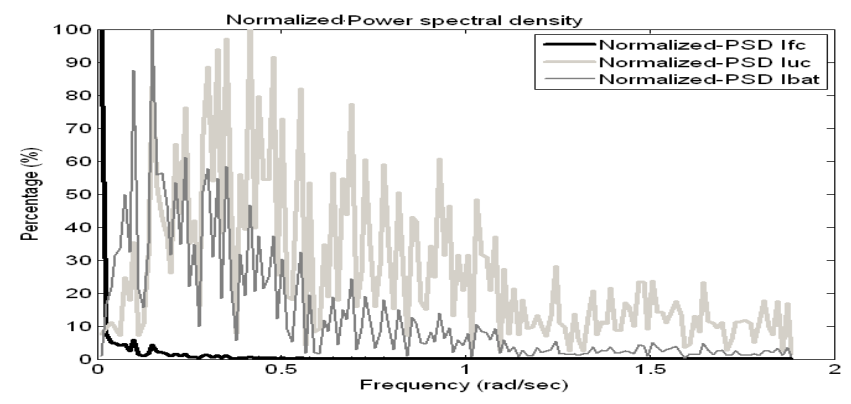

Fig. 12: Normalized power spectrum density of the sources' currents corresponding to IFSTTAR load profile.

\section{REFERENCES}

[1] A. Florescu, "Optimal energy control within electric vehicle (Gestion optimisée des flux énergétiques dans le véhicule électrique)," Ph.D. thesis. Grenoble University, Grenoble, France, 2012.

[2] C. Li, G. Liu, "Optimal fuzzy power control and management of fuel cell/battery hybrid vehicles," Journal of Power Sources, vol. 192, pp. 525-533, 2009.

[3] E. Ozatay, B. Zile, J. Anstrom , S. Brennan, "Power Distribution Control Coordinating Ultracapacitors and Batteries for Electric Vehicles," Proceedings of the 2004 American Control Conference Boston, Massachusetts, USA, pp. 4716-4721, 2004.

[4] D. Iannuzzi, "Use of Supercapacitors, Fuel cells and Electrochemical Batteries for Electric Road Vehicles: A Control Strategy," The $33^{\text {rd }}$ Annual Conference of the IEEE Industrial Electronics Society (IECON) Nov. 5-8, Taipei, Taiwan, pp. 539-544, 2007.

[5] P. Thounthonga, S. Raël, B. Davat, "Energy management of fuel cell/battery/supercapacitor hybrid power source for vehicle applications," Journal of Power Sources, vol. 193, pp. 376-385, 2009.

[6] A. Kuperman, I. Aharon, "Battery-ultracapacitor hybrids for pulsed current loads," Renewable and Sustainable Energy Reviews, vol. 15 pp. 981-992, 2011.

[7] Z. Yu, D. Zinger, A. Bose, "An innovative optimal power allocation strategy for fuel cell, battery and supercapacitor hybrid electric vehicle," Journal of Power Sources, vol. 196, pp. 2351-2359, 2011.

[8] J. Wong, N.R.N. Idris, M. Anwari, T. Taufik, "A Parallel EnergySharing Control for Fuel cell-Battery-Ultracapacitor Hybrid Vehicle," Proceedings of Energy Conversion Congress and Exposition (ECCE) IEEE, pp. 2923- 2929, 2011.

[9] A. Fadel, B. Zhou, "An experimental and analytical comparison study of power management methodologies of fuel cell-battery hybrid vehicles," Journal of Power Sources, vol. 196, pp. 3271-3279, 2011.

[10] A. Florescu, A.I. Bratcu, I. Munteanu and S. Bacha, "Energy Management System within Electric Vehicles Using Ultracacitors : An LQGoptimal-control-based Solution," CAO 2012 (15th IFAC Workshop on Control Applications of Optimization), Rimini, Italy, 2012.

[11] A. Florescu, I. Munteanu, A.I. Bratcu and S. Bacha, "FrequencySepation-Based Energy management Control Strategy of Power Flows within Electric Vehicles using Ultracapacitors," IECON 2012 (38th Annual Conference of the IEEE Industrial Electronics Society), Montréal, Canada, 2012.

[12] A. Florescu, I. Munteanu, A.I. Bratcu, A. Rumeau and S. Bacha, "Results Concerning Ultracapacitor-based Energy Management Strategy 
within Electric Vehicles," ICSTCC 2012 (16th International Conference on System Theory, Control and Computing), Sinaia, Romania, 2012.

[13] K. Åstraöm, T. Haägglund, "The Control Handbook, PID Control" (Ed. W.S. Levine), CRC Press, pp. 198-209, 1996.

[14] C. Poussot-Vassal, "Multi-variables LPV robust control for vehicle chassis (Commande Robuste LPV Multivariable de Chssis Automobile)," Phd thesis. Grenoble INP, Grenoble, France, 2008.

[15] P. Apkarian, P. Gahinet and G. Becker, "Self-scheduled Hinf Control of linear parameter-varying system: a design example," Automatica, vol. 31, no. 9, pp. 1251-1261, 1995. 